\title{
Mucosal Melanoma of the Head and Neck Pathologic TNM Finding v7
}

National Cancer Institute

\section{Source}

National Cancer Institute. Mucosal Melanoma of the Head and Neck Pathologic TNM

Finding v7. NCI Thesaurus. Code C89130.

A pathologic finding about one or more characteristics of mucosal melanoma of the head and neck, following the rules of the TNM AJCC v7 classification system. 